\title{
Anaplastic/large cell medulloblastoma
}

INSERM

\section{Source}

INSERM. (1999). Orphanet: an online rare disease and orphan drug data base.

Anaplastic/large cell medulloblastoma. ORPHA:251855

Anaplastic/large cell medulloblastoma is a histological variant of medulloblastoma (see this term), an embryonic malignancy, associated with extremely low survival rates and a high risk of metastatic disease and manifesting with symptoms of increased intracranial pressure such as vomiting, headache, listlessness, papilledema and diplopia. 